\title{
PENGARUH PEMBELAJARAN INOVATIF BERBASIS DEEP DIALOG/CRITICAL THINKING (DD/CT)TERHADAP KEMAMPUAN BERPIKIR KRITIS DAN HASIL BELAJAR SISWA PADA MATAPELAJARAN EKONOMI DI MA NW SURALAGA
}

\author{
Qurratul Aini ${ }^{1}$, Multazam ${ }^{2}$ \\ ${ }^{1}$ Prodi pendidikan ekonomi, FKIP Universitas Hamzanwadi \\ Email: aqurratul77@gmail.com \\ ${ }^{2}$ Pendidikan ekonomi, FKIP Universitas Hamzanwadi \\ Email: multazam@gmail.com
}

\begin{abstract}
Abstract: This study aims to determine the effect of the innovative learning-based deep dialogue / critical thinking (DD / CT) against critical thinking skills and student learning outcomes in economic lesson in MA NW Suralaga. This type of research using a quasi-experimental methods (quasi experimental) research design Non-Equivalent Control Group Design. The sampling technique is cluster random sampling. The study population was all students of class $\mathrm{X}$ in the MA NW Suralaga. X Class B as an experimental class, while the class X C as the control class. The instrument used in this study is the observation sheet and tests. The results of calculations prerequisite test data analysis done by the normality test results homogeneity test using the test of Bartlet, while the hypothesis test result obtained $\mathrm{t}$ between models of deep dialogue / critical thinking (DD / CT) with the critical thinking skills of students at $4: 18$, while $t$ table on significance level $\alpha=0.05(5 \%)$ is 2.098 , whereas the t between models of deep dialogue / critical thinking (DD / CT) with the learning outcomes of 7.9 and t table of 2.098. Because $t$ count $>\mathrm{t}$ table means $\mathrm{H} 0$ rejected and Ha accepted. Thus, the results of this study indicate that the use of models of deep dialogue / critical thinking (DD / CT) effect on critical thinking skills and student learning outcomes MA NW Suralaga.
\end{abstract}

Keywords: Learning Model deep dialogue / critical thinking (DD / CT), Critical Thinking and Learning Outcomes student

\begin{abstract}
Abstrak
Penelitian ini bertujuan untuk mengetahui Pengaruh pembelajaran inovatif berbasis deep dialog/critical thinking (DD/CT) terhadap kemampuan berpikir kritis dan hasil belajar siswa pada matapelajaran ekonomi di MA NW Suralaga. Jenis penelitian menggunakan metode eksperimen semu (quasi experiment) dengan desain penelitian Non Equivalent Control Group Design. Teknik pengambilan sampel cluster random sampling. Populasi penelitian ini adalah seluruh siswa kelas X di MA NW Suralaga. Kelas X B sebagai kelas eksperimen, sedangkan kelas X C sebagai kelas kontrol. Instrumen yang digunakan dalam penelitian ini adalah lembar observasi dan tes. Hasil perhitungan uji prasyarat analisi data dilakukan dengan uji normalitas hasil uji homogenitas dengan menggunakan uji bartlet, sedangkan hasil uji hipotesis di peroleh t hitung antara model deep dialog/critical thinking (DD/CT) dengan kemampuan berpikir kritis
\end{abstract}


siswa sebesar 4.18, sedangkan $t$ tabel pada taraf signifikansi $\alpha=0,05(5 \%)$ adalah 2,098, sedangkan $\mathrm{t}$ hitung antara model deep dialog/critical thinking (DD/CT) dengan hasil belajar sebesar 7,9 dan t tabel sebesar 2,098. Karena $t$ hitung $>\mathrm{t}$ tabel berarti H0 ditolak dan Ha diterima. Dengan demikian, hasil penelitian ini menunjukkan bahwa penggunaan model deep dialog/critical thinking (DD/CT) berpengaruh terhadap kemampuan berpikir kritis dan hasil belajar siswa MA NW Suralaga.

Kata kunci: Model Pembelajaran deep dialog/critical thinking (DD/CT), Berpikir kritis dan Hasil Belajar.

\section{PENDAHULUAN}

Untuk mencapai keberhasilan dalam pendidikan ini tentu tidak semudah membalik telapak tangan. salah satu faktor keberhasilan pendidikan adalah kurikulum yang releven dengan perkembangan ilmu pengetahuan dan teknologi, serta dinamika kebutuhan masyarakat, sehingga kurikulum disusun sedemikian rupa untuk mewujudkan tujuan pendidikan nasional dengan memperhatikan tahap perkembangan siswa dan kesesuaian dengan lingkungan, kebutuhan pembangunan nasional, serta perkembangan ilmu pengetahuan dan teknologi (Rodiatun, 2012:1).

Dalam kegiatan belajar mengajar (KBM) guru dan peserta didik terlibat dalam sebuah intraksi dengan bahan pelajaran sebagai mediumnya. dalam intraksi itu peserta didiklah yang lebih aktif, bukan guru (Djamarah dan Zain, 2010:106).

Dalam pelaksanaan proses pembelajaran sangat diperlukan berbagai teknik-teknik serta strategi pembelajaran yang tepat untuk menunjang keberhasilan suatu pembelajaran seperti memilih metode yang relevan, proses pembelajaran yang dilakukan oleh guru cenderung menekankan pada aspek pengetahuan dan pemahaman, salah satu masalah yang dihadapi dunia pendidikan adalah masalah lemahnya proses pembelajaran. Dalam proses pembelajaran, anak kurang didorong untuk mengembangkan kemampuan berpikir. Proses pembelajaran didalam kelas diarahkan kepada kemampuan anak untuk menghafal informasi, otak anak dipaksa untuk mengingat dan menimbun berbagai informasi tanpa dituntut untuk memahami informasi yang diingatnya itu untuk menghubungkannya dengan kehidupan sehari-hari. Akibatnya, ketika anak didik tidak lulus dari sekolah, mereka pintar secara teoritis, tetapi mereka miskin aplikasi 
(Sanjaya, 2005:1). Guru selama ini lebih banyak memberikan ceramah dan latihan mengerjakan soal-soal dengan cepat tanpa memahami konsep secara mendalam. Hal ini menyebabkan siswa kurang terlatih untuk mngembangkan daya nalarnya dalam memecahkan permasalahan dan mengaplikasikan konsep-konsep yang telah di pelajari dalam kehidupan nyata. sehingga kemampuan berpikir kritis siswa kurang dapat berkembang dengan baik.

Menurut Richart W. Paul yang dikutip oleh Kasdian dan Febian (dalam jurnal formatif hal 192) "berpikir kritis adalah proses disiplin secara intelektual dimana seseorang secara aktif dan terampil memahami mengaplikasikan, menganalisis, mensintesakan dan mengevaluasi sebagai informasi yang dia kumpulkan atau yang dia ambil dari pengalaman, pengamatan, refleksi yang dilakukannya, penalaran atau komunikasi yang dia lakukan”. Jadi seseorang yang berpikir kritis akan selalu aktif dalam memahami dan menganalisis semua informasi yang ia dapatkan.

Hasil belajar adalah sejumlah pengalaman yang diperoleh siswa mencakup ranah kognitif, afektif, dan psikomotor (Rusman 2012:122). Hasil belajar kognitif merupakan tingkat pemahaman siswa terhadap materi. Hasil belajar aspek afektif lebih berorientasi pada pembentukan sikap melalui proses pembelajaran. Sedangkan hasil belajar psikomotor berkaitan dengan hasil kemampuan fisik siswa. Upaya untuk meningkatkan hasil belajar siswa dalam pembelajaran merupakan salah satu tugas dan tanggung jawab semua guru atau pendidik, karena fungsi utama guru ialah merancang, mengelola, dan mengevaluasi pembelajaran.

Saat ini hampir sebagian besar guru kurang memperhatikan model pembelajaran dalam setiap penampilan mengajar. kebanyakan guru masih menggunakan metode yang bersifat konvensional, dimana penyampaiannya lebih banyak didominasi oleh guru yang gaya belajarnya cenderung bersifat instruktif, serta proses komunikasi satu arah sedangkan siswa cenderung diam dan pasif menerima pelajaran. Guru hanya menjalankan tugasnya sebagai pengajar yang merupakan sumber informasi satu-satunya bukan sebagai fasilitator belajar. Hal ini menyebabkan aktivitas siswa mengalami hambatan sehingga hasil belajarnya 
sulit mengalami peningkatan.

Berdasarkan observasi dan wawancara serta dokumen yang peneliti dapatkan pada tanggal 8 April 2016/2017, melalui pak Saepuddin S.Pd selaku guru mata pelajaran ekonomi pada kelas X MA NW Suralaga, metode pembelajaran yang biasa digunakan adalah metode konvensional seperti ceramah dan tanya jawab, dimana guru masih mendominasi kegiatan pembelajaran, dan siswa selalu pasif. Siswa hanya mendengarkan ceramah dan mencatat, sehingga informasi dan pemahaman yang didapatkan oleh siswa hanya sebatas pada penjelasan yang diberikan oleh guru. Pembelajaran seperti ini menyebabkan siswa tidak aktif di kelas dan siswa jarang mengeluarkan pendapat/ide-ide/gagasan, sehingga siswa belum mampu berpikir kritis dalam menemukan solusi pemecahan masalah yang berkaitan dengan materi yang diajarkan oleh guru tersebut. Salah satu akibat dari kondisi tersebut adalah ratarata hasil ulangan semester untuk pelajaran Ekonomi yang dicapai siswa di kelas $\mathrm{X}$ masih rendah, tidak sesuai dengan target nilai KKM yaitu 70 .

Tabel 1

Nilai Semestser Kelas X MA NW Suralaga

\begin{tabular}{cccccc}
\hline No & Kelas & Jumlah siswa & Nilai rata-rata & $\begin{array}{l}\text { Jumlah Nilai } \\
\text { tertinggi }\end{array}$ & $\begin{array}{l}\text { Jumlah Nilai } \\
\text { Terendah }\end{array}$ \\
\hline 1 & X-A & 28 & 62 & 81 & 38 \\
\hline 2 & X-B & 21 & 56 & 71 & 41 \\
\hline 3 & X-C & 18 & 52 & 62 & 37 \\
\hline
\end{tabular}

(Sumber dari guru MA NW Suralaga)

Berdasarkan kondisi di MA NW Suralaga, diperlukan suatu pendekatan pembelajaran dengan melakukan tindakan yang melibatkan seluruh siswa untuk lebih aktif dalam kegiatan pembelajaran. Adapun pendekatan yang dimaksud adalah dengan melakukan pembelajaran inovatif dengan menerapkan pembelajaran berbasis dialog/mendalam dan berpikir kritis (deep dialog/critical thinking) dalam meningkatkan kemampuan berpikir kritis dan hasil belajar siswa. Menurut Arthana (2010:17) model pembelajaran berbasis deep 
dialog/critical thinking adalah suatu pendekatan pembelajaran yang mengakses paham konstruktivis dengan menekankan dialog mendalam dan berpikir kritis dalam mendapatkan pengetahuan dan pengalaman. adapun kelebihan dan kekurangan dari model pembelajaran deep dialog/critical thinking antara lain : kelebihan deep dialog/critical thinking yaitu (1) dapat digunakan melatih peserta didik untuk berpikir kritis dan imajinatif, menggunakan logika, menganalisis fakta-fakta dan melahirkan imajinatif atas ide-ide lokal dan tradisional. Sehingga peserta didik dapat membedakan mana yang disebut berpikir baik dan tidak baik, (2) deep dialog/critical thinking menekankan pada nilai, sikap, kepribadian, mental emosional dan spiritual sehingga peserta didik belajar dengan menyenangkan dan bergairah, (3) deep dialog/critical thinking merupakan pendekatan yang dapat dikolaborasikan dengan berbagai metode yang telah ada dan dipergunakan oleh dosen selama ini. selanjutnya kekurangan dari model pembelajaran deep dialog/critical thinking secara umum adalah pada tahap persiapan awalnya karena pada tahap persiapan awal akan digunakannya pendekatan ini karena seorang guru harus mempersiapkan dengan persiapan yang lebih matang sehingga siswa mampu menerapkan pendekatan deep dialog/critical thinking ini. selain itu mempersyaratkan siswa memiliki latar belakang yang cukup tentang topik atau masalah yang didiskusikan, apatis bagi siswa yang tidak terbiasa berbicara dalam forum selain itu juga akan menyita waktu lama dan juga kurang tepat jika digunakan pada tahap awal proses belajar bila siswa baru diperkenalkan kepada bahan pembelajaran baru.

Adapun tujuan penelitian ini yaitu untuk mengetahui pembelajaran inovatif berbasis deep dialoque/critical thinking terhadap kemampuan berfikir kritis siswa kelas X MA NW Suralaga dan untuk mengetahi pengaruh pembelajaran inovatif berbasisi deep dialoque/critical thinking terhadap hasil belajar siswa kelas X MA NW Suralaga.

\section{METODOLOGI PENELITIAN}

Jenis penelitian yang digunakan adalah jenis penelitian eksperimen semu (quasi experiment), bentuk desain eksperimen ini merupakan pengembangan dari 
true eksperimen design yang sulit dilaksanakan. Desain ini mempunyai kelompok kontrol, tetapi tidak dapat berfungsi sepenuhnya untuk mengontrol variablevariabel luar yang mempengaruhi pelaksanaan eksperimen. Sugiyono (2014: 114).

Penelitian ini didahului dengan penentuan kelompok eksperimen dan kelompok kontrol melalui pengacakan kelas karna tidak dapat mengubah kelas yang telah terbentuk sebelumnya. Pre-test digunakan untuk menyetarakan pengetahuan awal kedua kelompok, sedangkan post-test digunakan untuk mengukur hasil belajar siswa setelah diberi perlakuan Sugiyono (2014: 76)

Populasi dalam penelitian ini adalah seluruh siswa kelas X MA NW Suralaga. tahun pelajaran 2015/2016 yang terdiri dari kelas 3 kelas yaitu X A, X $\mathrm{B}$ dan $\mathrm{X} \mathrm{C}$, dengan jumlah siswa 64 orang. Teknik yang digunakan untuk mengambil sampel dalam penelitian ini adalah cluster random sampling. Hasil teknik cluster random sampling diperoleh kelas X B dan X C sebagai sampel, kemudian kelas tersebut diundi untuk menentukan kelas eksperimen dan kelas kontrol. Hasilnya diperoleh kelas X B sebagai kelas eksperimen dan kelas X C sebagai kelas kontrol. Jenis data yang digunakan dalam penelitian ini adalah: Data kualitatif adalah berupa hasil observasi guru dan hasil belajar siswa ketika kegiatan proses belajar mengajar dikelas dan Data kuantitatif adalah berupa skor hasil penelitian hasil test/evaluasi belajar yang diberikan pada setiap akhir kegiatan belajar.

Teknik Pengumpulan Data Untuk memperoleh data sesuai dengan tujuan penelitian yaitu: Lembar Observasi Kemampuan Berpikir Kritis Siswa dan Tes Hasil Belajar. Teknik Analisis data menggunakan uji prasyarat dan uji hipotesis. Uji prasyarat antara lain 1) Uji Normalitas. Uji normalitas dilakukan untuk mengetahui apkah sampel yang diambil dalam penelitian distribusi normal atau tidak, Uji kenormalan yang digunakan peneliti adalah Uji Liliefors. Langkahlangkah uji normalitas sebagai berikut 2) Uji Homogenitas. Uji ini digunakan untuk mengetahui apakah populasi penelitian mempunyai variansi yang sama atau tidak. Untuk menguji homogenias variansi ini digunakan uji barlett sebagai berikut : 


$$
\begin{aligned}
& X^{2 \text { hitung }}=(\mathrm{In} 10)\left\{\mathrm{B}-\left(\mathrm{E} d k \log s_{i} 2\right)\right. \\
& X_{\text {tabel }}^{2}=X_{(a, k-1)}^{2}
\end{aligned}
$$

Hipotesis dari uji Barlett sebagi berikut :

$\mathrm{H} 0=$ Data Homogen

H1 = Data tidak homogen

Langkah-langkah uji Barlett sebagai berikut:

$X^{2}$ hitung $\leq$ maka H0 diterima

\section{HASIL DAN PEMBAHASAN}

Dari hasil analisis data hasil observasi tingkat kemampuan berpikir kritis siswa selama proses belajar mengajar berlangsung pada kelas eksperimen tercantum pada pengelompokan skor kemampuan berpikir kritis siswa. Berdasarkan acuan ini nilai rata-rata skor 20-34 dikategorikan sangat kurang, 3549 dikategorikan kurang, 50-59 dikategori cukup, 60-74 dikategorikan tinggi, dan 75-100 dikategorikan sangat tinggi.

Rata-rata skor tingkat kemempuan berpikir kritis siswa untuk kelas eksperimen pre-test dikategorikan cukup dan post-test dikategorikan tinggi, dan untuk kelas kontrol pre-test dikategorikan cukup dan post-test dikategorikan cukup. Adapun rata-rata skor tingkat kemampuan berpikir kritis siswa dapat dilihat pada tabel berikut ini.

Tabel 2

Rata-Rata Skor Tingkat Kemampuan Berpikir Kritis Siswa

\begin{tabular}{llllll}
\hline Kelas & Variabel & Pre- & Kategori & Post-test & Kategori \\
\hline Eksperimen & $\begin{array}{l}\text { Deep } \\
\text { dialog/critical }\end{array}$ & 55.6 & Cukup & 62.1 & Tinggi \\
\hline Kontrol & Talking Stick & 52.7 & Cukup & 56.4 & Cukup \\
\hline
\end{tabular}

Data dalam penelitian ini diperoleh dari data hasil belajar pada ranah kognitif. Penelitian ini melibatkan dua kelas sebagai sampel yaitu kelas X B yang berjumlah 21 orang sebagai kelas eksperimen yang menggunakan model pembelajaran DD/ CT dan kelas X C sebagai kelas kontrol yang berjumlah 18 orang dengan menggunakan metode Talking Stick dalam proses pembelajaran ekonomi sehingga jumlah siswa adalah 39 orang. 
Deskripsi hasil pre-test dan post-test kelompok eksperimen dan kelompok kontrol dapat dilihat dalam tabel dan gambar dibawah ini:

Tabel: 3

Hasil Nilai Pre-test Dan Post-test Kelas Ekperimen Dan Kelas Kontrol

\begin{tabular}{|l|c|c|c|c|}
\hline Keterangan & \multicolumn{2}{|c|}{ Kelas Eksperimen } & \multicolumn{2}{c|}{ Kelas control } \\
\hline Jumlah sampel & \multicolumn{2}{|c|}{21} & \multicolumn{2}{c|}{18} \\
\hline Penilaian & Pre-test & Post test & Pre-test & Post test \\
\hline Nilai maksimal & 78 & 87 & 74 & 83 \\
Nilai minimal & 52 & 52 & 52 & 52 \\
Mean (X) & 62.5 & 72.9 & 62.6 & 67.4 \\
Median & 61 & 74 & 63 & 67.5 \\
Modus & 65 & 78 & 65 & 61 \\
Standar deviasi & 7.13 & 10.25 & 5.93 & 7.98 \\
Jumlah siswa yang tuntas & 4 & 15 & 2 & 9 \\
\hline KKM & \multicolumn{4}{|l}{70} \\
\hline
\end{tabular}

(Sumber: Data Primer Diolah Peneliti)

Dari tabel di atas terlihat bahwa jumlah siswa yang tuntas paling banyak diperoleh pada hasil nilai post-test kelas eksperimen sebanyak 15 orang siswa dari 21 orang siswa dengan nilai rata-rata kelas sebesar 72,9.

Pengujian persyaratan analisis melalui uji normalitas data, homogenitas data dan uji hipotesis :

Uji Normalitas Data

Pembuktian normalitas data dilakukan untuk menguji apakah skor dalam variabel-variabel yang diteliti berdistribusi normal atau tidak. Untuk menganalisa datanya digunakan rumus chi-kuadrat $\left(\mathrm{x}^{2}\right)$. Hasil perhitungan $\left(\mathrm{x}^{2}\right)$ yang diperoleh kemudian dikonsultasikan dengan nilai $\left(\mathrm{x}^{2}\right)$ tabel dengan taraf signifikan 5\% dan derajat kebebasan ( $\mathrm{n}-1)$, dimana $\mathrm{n}$ adalah banyaknya siswa dan kriteria yang digunakan adalah sebagai berikut : jika $x^{2}$ hitung $<x^{2}$ tabel dengan taraf signifikansi 5\% dan maka hipotesis normalitas diterima artinya data dinyatakan normal, sebaliknya jika $\mathrm{x}^{2}$ hitung $>\mathrm{x}^{2}$ tabel dengan taraf signifikansi 5\% maka hipotesis normalnya ditolak artinya datanya tidak berdisteribusi normal. Dalam pengujian Normalitas data, peneliti dengan menggunakan program Excel Windows. 
Tabel: 4

Rangkuman hasil normalitas data kelompok eksperimen dan kelompok kontrol

\begin{tabular}{|c|l|c|c|c|c|}
\hline \multirow{2}{*}{ No } & \multirow{2}{*}{ Kelas } & \multicolumn{2}{|c|}{$X^{2}$} & \multirow{2}{*}{$\begin{array}{c}2 \\
\text { Hitung }\end{array}$} & \multirow{2}{*}{ Kriteria } \\
\cline { 3 - 4 } & & \multicolumn{2}{|c|}{ Tabel (5\%) } & \\
\hline 1 & Eksperimen & -9.74 & -3.20 & 11.070 & Normal \\
2 & Kontrol & 1.27 & -0.37 & 9.488 & Normal \\
\hline
\end{tabular}

Uji Homogenitas Data

Untuk pengujian homogenitas data digunakan teknik pengujian Bartlet.

Tabel: 5

Ringkasan perhitungan statistik sederhana post-test untuk kelompok

\begin{tabular}{lcccc}
\multicolumn{5}{c}{ eksperimen dan kontrol } \\
\hline Sample & $(\mathrm{n}-1)$ & $1 /(\mathrm{n}-1)$ & $\mathrm{S}_{\mathrm{t}}$ & $(\mathrm{n}-1) \log$ \\
& & & & $\mathrm{S}_{\mathrm{t}}{ }$ \\
\hline Eksperimen & 20 & 0,05 & 10.25 & 20.22 \\
Kontrol & 17 & 0,06 & 7.98 & 15.33 \\
\hline Jumlah & 37 & 0,11 & 18.23 & 35.55 \\
\hline
\end{tabular}

Kemudian untuk menentukan variasi gabungan dari kelompok eksperimen dan kelompok control dengan rumus sebagai berikut :

$$
\begin{aligned}
& (n-1) S^{2}+ \\
& \mathrm{S}^{2}=\frac{(n-1) S_{1}^{2}}{n_{1}+} \\
& \begin{array}{c}
n_{2} \\
-2
\end{array} \\
& =\frac{20(10.25)+17(7.98)}{37} \\
& =\frac{205+135.66}{37}=9.21
\end{aligned}
$$

Karna $\mathrm{S}^{2}=9.21$ maka $\log \mathrm{S}^{2}=0.964$ setelah itu dilakukan pengujian homogenitas data dengan menggunakan tehnik uji bartlet sebagai berikut:

$$
\begin{aligned}
& \mathrm{B}=\operatorname{LOG} S^{2}\left(n-1^{2}\right) \\
& =(0.9 \\
& 64)(3 \\
& \quad 7) \\
& =35.67
\end{aligned}
$$




$$
\begin{aligned}
& \text { Untuk } X^{2} \text { hitung }=\left(\text { In 10) } \left\{\mathrm{B}-\sum(n-1) \log _{1}^{2}\right.\right. \\
& =(2,30)(35.67-35.55) \\
& =0,28 \\
& \mathrm{X}^{2} \text { hitung }=0,28 \\
& \mathrm{X}^{2} \text { tabel }=3.841
\end{aligned}
$$

Dengan kriteria keputusan $\mathrm{x}^{2}$ hitung $<\mathrm{x}^{2}$ tabel berarti signifikansi dan homogen. Dengan derajat kebebasan $(\mathrm{dk}=2-1)$ dengan taraf signifikansi $5 \%$ maka dengan kriteria diatas didapatkan $\mathrm{x}^{2}$ hitung $=0,28$ dan $\mathrm{x}^{2}$ tabel $=3.841$ jadi $\mathrm{x}^{2}$ hitung $0,28<\mathrm{x}^{2}$ tabel 3.841 berarti signifikan dan homogen.

\section{Uji Hipotesis}

Setelah terpenuhinya persyaratan analisis (uji normalitas dan homogenitas), maka dapat dilakukan uji hipotesis dengan menggunakan rumus $t$ test dengan poled varian untuk mengetahui apakah terdapat pengaruh yang positif dan signifikan model pembelajaran kooperatif tipe deep dialog/critical thinking terhadap hasil belajar siswa pada pelajaran Ekonomi kelas X MA NW Suralaga tahun. Diambil dua kelas sebagai sampel, dimana kelas XB sebagai kelas eksperimen menggunakan deep dialog/critical thinking dan kelas $\mathrm{XC}$ sebagai kelas kontrol menggunakan metode talking stick.

Perhitungan Uji Hipotesis kemampuan berpikir kritis

Berdasarkan hasil uji Hipotesis dengan poled varian untuk variabel kemampuan berpikir kritis siswa di peroleh thitung $=4.18$ dengan derajat kebebasan $\mathrm{dk}=\mathrm{n}_{2}-1=17 \mathrm{dan} \mathrm{dk}=\mathrm{n} 1-1=20$. Dengan taraf kesalahan 5\%. Untuk lebih jelasnya perhatikan tabel di bawah ini :

Tabel: 6

Hasil uji hipotesis kemampuan berpikir kritis

\begin{tabular}{cccllll}
\hline No & N (Sampel) & & $\mathrm{S}^{2}$ & Thitu & Ttabe \\
\cline { 1 - 4 } 1 & 21 & 62 & 68 & & \\
\cline { 1 - 5 } 2 & 18 & 56.4 & 23.7 & & 4.18 & 2.098 \\
\hline
\end{tabular}


Berdasarkan tabel di atas, diperoleh t tabel $=2,098$. Karena thitung sebesar 4.18 dan tabel sebesar 2.098 dengan taraf uji 5\% maka tabel lebih kecil dari thitung sehingga hipotesis nihil (Ho) yang diajukan di tolak dengan kata lain hipotesis alternative (Ha) diterima.

Hipotesis alternative (Ha) diterima artinya bahwa dengan menerapkan pembelajaran model Deep Dialog/Critical Thinking $(d d / c t)$ terdapat pengaruh terhadap kemampuan berpikir kritis siswa pada mata pelajaran ekonomi kelas $X$ di MA NW Suralaga.

Perhitungan Uji hipotesis Hasil belajar

Berdasarkan hasil uji hipotesis variabel hasil belajar diperoleh thitung $=$ 7.9 dengan derajat kebebasan $\mathrm{dk}=\mathrm{n} 1-1=21-1=20$ dan $\mathrm{dk}=\mathrm{n} 2-1=18$ $-1=17$ Dengan taraf kesalahan 5\%,. Untuk lebih jelasnya perhatikan table d bawah ini :

Tabel: 7

Hasil Uji Hipotesis Kemampuan Berpikir Kritis

\begin{tabular}{|c|c|c|c|c|c|}
\hline No & $\mathrm{N}$ (sampel) & & $S^{2}$ & Thitung & Ttabel \\
\hline 1 & 21 & 72.9 & 10.25 & & \\
\hline 2 & 18 & 67.4 & 7.98 & 7.9 & 2.098 \\
\hline
\end{tabular}

Maka tabel $=2.098$, Karna thitung $=7.9$ dan $\mathrm{t}$ table $=2.098$ dengan taraf uji 5\% maka tabel lebih kecil dari thitung, sehingga hipotesis nihil (Ho) yang diajukan di tolak dengan kata lain hipotesis alternative (Ha) diterima. Hipotesis alternative (Ha) diterima artinya bahwa dengan menerapkan pembelajaran model Deep Dialog/Critical Thinking $(d d / c t)$ terdapat pengaruh terhadap hasil belajar siswa pada mata pelajaran ekonomi kelas X di MA NW Suralaga.

\section{KESIMPULAN}

Penelitian ini bertujuan Untuk Mengetahui pengaruh pembelajaran inovatif berbasis deep dialog/critical thinking (DD/CT) terhadap kemampuan berpikir kritis dan hasil belajar siswa pada matapelajaran ekonomi di MA NW 
Suralaga.

Dengan metode penelitian eksperimen. Berdasarkan data analisis yang terkumpul yang dilakukan maka dapat ditarik kesimpulan Bahwa dengan menggunakan pembelajaran inovatif berbasis deep dialog/critical thinking (DD/CT) terdapat pengaruh yang positif dan signifikan terhadap kemampuan berpikir kritis siswa pada mata pelajaran ekonomi kelas x di MA NW Suralaga dan dengan menggunakan pembelajaran inovatif berbasis deep dialog/critical thinking juga terdapat pengaruh yang positif dan signifikan terhadap hasil belajar siswa pada pelajaran ekonomi kelas X. Hal ini dapat kita lihat dari nilai yang diperoleh antara t-hitung dengan t-tabel, dimana t-hitung lebih besar dari t-tabel (7.9 $>2.098$ ) pada taraf signifikan $5 \%$.

\section{DAFTAR RUJUKAN}

Dimyanti \& Mudjiono, belajar dan pembelajaran (Jakarta:Rineka Cipta. Cet.3, 2006)

Hafriani, Novi. Penerapan pembelajaran kontekstual Berbasis Deep Dialoque/Critical Thinking untuk meningkatkan kemampuan komunikasi matematis siswa SMP. Skripsi universitas Pendidikan Indonesia: tidak dipublikasikan, 2013).

Ketut P.Arthana, "pembelajaran inovatifberbasis deep dialoque/critcal Thinking”, jurnal Tehknologi pendidikan, Vol.10, No.1, April 2010, h.17.

Mardiningsih, Anis (2017) "Pengaruh model pembelajaran deep dialoque and critical thinking terhadap kemampuan berfikir kritis matematis peserta didik kelas VIII SMPN 24 Bandar Lampung T.A 2016/2017”. Undergraduated thesis, UIN Raden Intan Lampung.

M.Ngalim Purwanto, Psikologi Pendidikan (Bandung: Remaja Posda Karya, 2002)

Twista Ria, "penerapan pembelajran model deep dialoque/critical thinking untuk meningkatkan aktivitas dan hasil belajar PKn siswa kelas VI SDN Arjosari 2 kecamatan Blimbing kota malang. Skripsi universitas negeri malang, 2014)

Sugiyono, metodologi teknik penelitian ((Jakarta:Rineka Cipta : 2014 